\title{
The Early Expansion of English Trade in Suba Bengal
}

\author{
Dr. Pradipta Acharya \\ (Department of History Purnidevi Chowdhury Girls' College, Bolpur, Dist: Birbhum, \\ Pin- 731204, West Bengal, India)
}

\begin{abstract}
The coming of the English East India Company to Bengal and their settlement over here was an important landmark in the history of Bengal and India as a whole. It was from the very early stage of the seventeenth century that we could see their efforts to establish their stronghold over Bengal which is known from the letters of Sir Thomas Roe. On the other hand the agents of the Dutch East India Company were also eager to establish their commercial relations with Bengal as is known from the letter of Van Berchem (the Director of the Dutch Factories of Coromandel).

The English from their very early phase were interested in establishing a factory at Pipili in Orissa. However their hope did not materialised and they establish their first factory at Patna in Eastern India. Though, the hope of establishing a factory at Orissa by them was never stopped. The English sent two ships again at Pipili. Finally in AD 1633 the English factory established at Balasore which was at that time under the Bengal Suba (province). One of the main reasons behind the establishing of a factory at Balasore was the easy availability of Cotton cloth and above all the direct opening through sea.
\end{abstract}

\section{Introduction}

Bengal has a rich history of its own. It was from the very ancient time that many invaders, travellers and traders came to Bengal. Bengal was also known for its rich resources and go get it traders like Arabian Muslims, Portuguese, Dutch, English came here and tried to occupy it by diplomacy or by force and among those the English were the most important. They came Bengal in such a situation when Portuguese had already established their supremacy over Asiatic trade and the Dutch traders were eager to establish their power in Bengal trade. On the other hand as we know that Bengal was under the sway of the Mughal power who had a very strong control over Bengal. So, whoever wants to open up trade with Bengal should have proper permission of the Mughal Emperor/Subadar. However to accrue permission was not at all easy and the companies have to keep patients for that and the English east India company was not an exception. In this short paper i will try to explore this history.

The coming of the English East India Company to Bengal and their settlement over here was an important landmark in the history of Bengal and India as a whole. During the time under review Bengal means not only the present west Bengal and Bangladesh but Orissa and some parts of Bihar was also under the paradigm of Suba Bengal. It was from the early seventeenth century that we could see their constant effort to establish a direct commercial relation with Bengal centreing around Hooghly. From the $16^{\text {th }}$ century Satgaon began to decline as port due to the silting of the river Saraswati which gave rise to a new port city just few miles south of Satgaon which came to be known as Hooghly. However, the English were very ambiguous regarding the trading opportunities in Bengal as is known from the letter of Sir Thomas Roe which he wrote to the English company in $24^{\text {th }}$ November, 1615 A.D. which runs as follows, “.... it is thought requisite that you seek trade in the territories of the Mogul in Bengale. I will inform myself of the finest port and procure a farman for residence of your factors..."1. Though it not very clear that about which port he told that but still we could simply guess that he was in his very first contact with Bengal was not in favour of the English trade with Bengal. Roe again told that, "...it will vent no commodity, neither is there any mart from Cathey or Tartary" ${ }^{2}$. In a letter written on $14^{\text {th }}$ Feb. 1618, Roe directly wrote to the English East India Company that "Bengala hath no ports...". . However he praised the quality of cotton cloth and sugar of Bengal. Roe's opinion about the non existence of good ports in Bengal is not over debate. Portuguese documents we could see the gradual rise of Hooghly as an important port of Bengal has already started from 1570s. Before the rise of Dutch and English power in Bengal trade it was the Portuguese who had established their stronghold over Bengal in 1500s. In the year A.D. 1628 at least one hundred Portuguese ships came to Bengal for the procurement of rice and for the selling of oil, butter, wax and some other necessary articles ${ }^{4}$.

The English East India Company was however eager to establish their trading relationship with Pipily of Orissa but due to the scarcity of good harbour their proposal did not materialised and finally it was Robert Hog who had established an English factory at Patna after getting permission from Mubaraq Khan, the Subadar of Bihar. As Patna was famous for the production of Calico and Silk the English took the opportunity and they became involved in this trade 5 . But the English fortune in its early trading relationship with Bengal was not so 
good. There was misunderstanding grew between the English factors of Patna and Prince Parvez, the new subadar of Bihar who came in position of Subadar Mubaraq Khan. Thus when the situation was going through this type of ups and downs, the English factory at Patna was destroyed by a devastating fire in A.D. 1621 . However the English were somehow able to manage their property but Robert Hog was directed by the English factors of Surat to leave Patna and the first attempt of the English to establish trading relationship with Bengal was thus came to a tragic end ${ }^{6}$.

The English made a second attempt to open up trade with Bengal and now they choose Orissa as the gateway and send two ships namely Hopewell and Perl to investigate trading opportunities at Pipily in A.D. 1631 and 1632 respectively but due to the bad weather these two mission did not fulfil ${ }^{7}$.

In the meantime the recapture of Hooghly by Shah Jahan from the hands of the Portuguese inspired the English to trade with Bengal more surely. Because it was the Portuguese pirates who forced all the merchant navies of different communities to obey the Cartaz system in between A.D. 1400 to 1500 and it was after the rise of the Dutch traders in India that the possibility of trading opportunities of the Portuguese became marginalised. However we could hear the voice of Portuguese traders in early 1600s but when the Portuguese were overpowered by Shah Jahan the other European trading Companies like the Dutch and the English came to light.

In A.D. 1633 the English made a third attempt to open up trade with Orissa and thus on $21^{\text {st }}$ April, 1633 some English traders under the leadership of Ralf Cartwright, Thomas Kohal came to Harishpur to meet Aga Muhammad Zaman the Subadar of Orissa (at that time) who being pleased gave the English the right of free trade and to establish a factory and open up a ship wreckage there. In his firman it was said that, "Here I, the said Nawab, vice-king and Governor of the country of Woodia (Orissa), under the great and mighty prince Pedesha Shah Sallem (Padshah Shahjahan), do give and grant free licence to the aforesaid Ralph Cartwright, merchant to trade, buy, sell, export and transport, by shipping either off or upon the shore, not paying any junken or custom...."

With the help of this firman the English established their factory at Hariharpur a place in between Cuttack and Harishpur. They also established another factory at Balasore in the same year. Very soon due to the silting up of the two rivers namely 'Alanka' and 'Patwa', Harishpur gradually lost its importance as an ideal place of anchorage and from this time Balasore because of its natural location, easy availability of the materials like, Cotton of various types (Gingham, Calico, Malmal etc) and some other necessary commodities became the main factory of the English at Orissa ${ }^{9}$. From Balasore the English used to export different products in different parts of India like, Bengal, Patna, Masulipatnam and various parts of Corromandel Coast and also South-east Asian states ${ }^{10}$.

However the English fortune at Balasore did not stayed a long and within a year they suffered strong opposition from the Dutch traders and faced the raids of the Arakan pirates. Besides the Portuguese were not completely abolished from the scenario so they also tried to regain their lost position at Suba Bengal. On the other hand the deaths of some important English officials like Thomas Kohal in $25^{\text {th }}$ Aug, 1633 gave English a setback. As a result the English officials of Fort St. George and Orissa were in search of another option which could give them much more security than the previous and in this time they shifted their view from Balasore to Hooghly ${ }^{11}$. So, with this the early expansion of the English trade in Bengal over.

\section{Reference}

[1]. Susil Chaudhury, Trade and Commercial Organization in Bengal, (Firma K.L.M, Calcutta, 1975), p. 12.

[2]. idid, p. 13

[3]. Ibid, p. 14

[4]. J.J.A. Camposs, History of the Portuguese in Bengal, (Calcutta Butterworth, Calcutta, 1919), p. 117.

[5]. L.S.S. O Malley, "Bengal District Gazetteers: Hooghly”, (Calcutta, 1912), p. 57.

[6]. Susil Chaudhury, op. cit, p. 17.

[7]. Ibid, 20 .

[8]. C.R. Wilson, 'The Early annals of the English in Bengal', Vol. I, (The Asiatic Society, 1895), rep. 1996, p. 11.

[9]. Jagadish Narayan Sarkar, 'Notes on Balasore and the English in the first half of the Seventeenth century' in Satish Chandra (ed.), Essays in Medieval Indian Economic History', (Munshiram Monoharlal Pvt. Ltd., 1987), p. 150.

[10]. Ibid, 153 .

[11]. Brush Annals, p. 410, 424, 430. 